\title{
Measuring the adaptability of fleet segments to a fishing ban: the case of the Bay of Biscay anchovy fishery
}

\author{
Margarita ANDRÉs ${ }^{\mathrm{a}}$ and Raúl PRELLEZO \\ AZTI, Technological Institute for Fisheries and Food, Marine Research Division, Txatxarramendi Ugartea z/g, 48395 Sukarrieta, Spain
}

Received 12 January 2011; Accepted 26 March 2012

\begin{abstract}
While fishing resources available to fishermen are becoming increasingly scarce, management actions that regulate these resources are becoming more restrictive, to such an extent that some fisheries remain closed for years. The anchovy fishery in the Bay of Biscay, which was closed for 5 years, from 2005 to 2009, is one of the most important sources of revenue for the Basque pelagic purse-seiner fleet. Throughout the course of this closure the fleet was forced to find alternative revenue streams. In the present study, the fishing alternatives were analysed before and during the anchovy fishery closure, defining an adaptability indicator to measure the ability of the fleet to cope with fisheries closures. Four differently-behaved segments were found within the purse-seiner fleet. Only one of these segments managed to maintain the same level of turnover during the anchovy closure, while the others could not reach a minimum level of adaptability. Compensation of the fishery closure through financial aid was studied, analysing the impact that public aid had on the profit of each segment and on the adaptability indicator.
\end{abstract}

Keywords: Anchovy fishery closure / Cluster analysis / Fleet segments / Adaptability / Engraulis encrasicolus / Atlantic Ocean

\section{Introduction}

In the current context of fisheries management, a good knowledge of fleet behaviour can provide improved and more equitable results (Salas and Gaertner 2004; Branch et al. 2006). According to Sethi (2010), the imperfect knowledge we have on the state of the world and the future represents a risk in fisheries management. If the risk is a possibility of a bad thing happening, a better knowledge of fleet behaviour can significantly reduce that risk. Weaknesses in understanding and in subsequent advice lead to policies and strategies that may either have little effect in the desired direction or may generate a different, possibly undesirable, response relative to that expected (Garcia and Charles 2008). Accordingly, Charles (2001) considers that one of the main causes of some fisheries collapses is the non-utilization of all sources of knowledge.

The lack of knowledge or non-use of available information has led to bad results in some fisheries. In the case of the cod fishery collapse on the Canadian Atlantic coast (Ruitenbeek 1996), one of the main conclusions was that fisheries managers must explicitly acknowledge the economic and social impacts of the proposed policies, and provide for adequate local involvement in decision-making and resource control. Another example of a lack of understanding in fisheries is the governance system for Alaska's Bristol Bay fishery (Hilborn 2006).

\footnotetext{
${ }^{a}$ Corresponding author: mandres@azti.es
}

In this case study, the biological objectives were successfully achieved, albeit with conflicting economic objectives.

Aranda et al. (2006) reinforced the idea that some management measures (such as the total allowable catches: TACs), while being potential tools to help achieve resource-protection goals, have often led to different failures in social or economics. Consequently, fisheries management should take into account information coming from different sources: biological, ecological, economic and social. Because fisheries management is management of people (Branch et al. 2006; Hilborn 2007), improved understanding of individuals and fleets, which behave rationally in response to regulation, could be a good tool to achieve desired objectives. Moreover, the more disaggregated the information, the better, because we can predict the effect of one management measure on each of the fleet segments. These effects can vary significantly from one segment to another; a fact that should be taken into account by managers.

In the specific case of fisheries closures, the response of fishers and their fishing effort to management actions is important when developing effective regulations (Powers and Abeare 2009). Time-space management regulations could have positive and negative effects on fleet behaviour and therefore on target species (Torres-Irineo et al. 2011). The resource manager should be aware of the dependence of fishermen on one particular stock when a fishery closure is decided. This would 
make is possible to establish a fair and equitable management system.

Management actions alter the economic conditions that fishers face and, in response, individual fishers make decisions changing their behaviour (Powers and Abeare 2009). As soon as a management measure is applied, fishers change their allocation of fishing effort (Lehuta et al. 2010). In this sense, fleet ability to adapt to adverse situations is essential for fleet survival. When management actions such as TACs or quotas affect more than one fleet, their ability to cope with the fisheries closures, i.e. the adaptability of each fleet needs to be taken into account to find the most equitable management rule. Furthermore, the manager should consider that, although spatial closures are designed to protect vulnerable species, they can also have unintended consequences (Fulton et al. 2011), effort displacements could occur leading to increased pressure on other species. In the North Sea when the European Commission closed a large area to all cod-related fishing fleets (Rijnsdorp et al. 2001; Poos and Rijnsdorp 2007) the number of trips to the non-closed area doubled. Accordingly, it is important to evaluate fisher's behaviour when a fishery is closed and how they are able cope with the new situation.

In the case of the Bay of Biscay Anchovy closure, some models have been developed that explain fishing trip choices and fishers' spatial behaviour (Vermard et al. 2008) in order to predict the response of effort allocation to shifts in management regimes, including fishing bans. The economic dependence of the French fleet on commercial species and their contributions to total landings were investigated to determine which fleets might be vulnerable due to high dependence on few species (Daures et al. 2009). The French fleet exploited around $20 \%$ of the anchovy TAC in 2010 (ICES WGANSA report 2010). The main fleet capturing anchovy in the Bay of Biscay is the Spanish purse-seiner fleet. Spanish purse-seiners between 14 and $38 \mathrm{~m}$ long fishing in the Bay of Biscay mainly harvest pelagic species such as European anchovy. In addition, in summer this fleet shifts its fishing gear to pole and line to target tuna (Thunnus spp.). Relationships between landings per unit effort and the variables that measure relative fishing power were analysed in Mahevas et al. (2011). Additionally, there is evidence that the financial performance of the Spanish fleet suffered a structural change after the implementation of the anchovy moratorium (Garza-Gil et al. 2011). However, as shown in the current paper, the Spanish purse-seiner fleet is not homogeneous. Hence, the current paper is focused on the effect that this ban had on each fleet segment. This was done using two concepts we define in this paper: the adaptability of the fleet segments to fishery closures and their dependency on a particular fishery.

The motivation of this paper is in line with the idea presented by Salas and Gaertner (2004), who considered that the knowledge of fleet dynamics is essential for effective management. The aim of this paper is to study the consequences of the anchovy fishery ban on the segments of this fleet and the measures to compensate fishers for their loss of income. The consequences of the ban are measured in terms of adaptability, using a single scale that helps to understand the influencing factors: turnover, technical characteristics, fishing profiles and fleet size.

\section{Background on the Bay of Biscay Basque pelagic fleet}

The purse-seiner fleet in the Bay of Biscay exploits a large diversity of pelagic species. However, anchovy (Engraulis encrasicolus), together with tunas (albacore tunas, Thunnus alalunga, and bluefin tuna, Thunnus thynnus, captured using poles and lines with live bait) have historically been the main resources of this fleet (Villamor et al. 2008). In 2004, anchovy revenues accounted for about $33 \%$ of the total landed value in the Bay of Biscay by the Basque purse-seiner fleet. Nonetheless, the anchovy stock became seriously reduced and, with it, the anchovy fishery of the Bay of Biscay. Small pelagic fish stocks, such as anchovy, are highly sensitive to environmental change and suffer large and variable natural mortality (Ibaibarriaga et al. 2011 or Andonegi et al. 2011). On July 1, 2005 the fishery was closed and the percentage of anchovy revenues declined to $1.5 \%$ of the total landing value of the Basque purse-seiner fleet. In 2006, the fishery was reopened and the average anchovy price reached a historical maximum of 11.3 euro $\mathrm{kg}^{-1}$; consequently, the percentage of anchovy revenues on total revenues increased 12 percentage points from 2005 to 2006. In 2007, the fishery was closed again and remained so continued until the end of 2009. In December 2009, the EC made the same proposal for keeping the fishery closed until June 2010. However, the Council of Fisheries Ministers of the EU that met in December 2009 decided to reopen the fishery for 2010 with a provisional total allowable catch (TAC) of $7000 \mathrm{t}$.

The Bay of Biscay fleet is a sequential multispecies fleet. In the first semester of the year, it devotes its fishing effort to mackerel (Scomber scombrus) and anchovy. In the second semester the majority of the vessels change fishing gear from purse seine to bait boat ${ }^{1}$, and to a lesser extent to trolling gear, to catch albacore and bluefin tuna. However, some vessels also allocate their fishing effort to coastal species such as Mediterranean horse mackerel (Trachurus mediterraneus), saddled bream (Oblada melanura), bogue (Boops boops), sargos (Diplodus spp.), striped sea bream (Lithognathus mormyrus), gilthead sea bream (Sparus aurata), axilary sea-bream (Pagellus acarne), bass (Dicentrarchus labrax), pandora (Pagellus erythrinus), Atlantic bonito (Sarda sarda) and chub mackerel (Scomber japonicus) (Arregi 2009). If we compare the Spanish fleet (Garza-Gil et al. 2011) with the Basque fleet we see that the fishing profiles are quite different.

Taking into account that aside from anchovy, the Basque purse-seiner fleet also has as main target species mackerel, bluefin tuna and albacore, the knowledge of the regulations and situations of these species would allow easier interpretation of the consequences of a closure in the anchovy fishery.

The main species targeted by the Basque purse-seiner fleet are regulated through TAC. The TAC of mackerel (western

\footnotetext{
1 In the baitboat fishing system, the bait is caught at dusk using purse seiner in shallow waters near the coast, such as bays and beaches. Using the bait the fishermen force the tuna to come in closer and fishing is done using individual rods (Rodriguez et al. 2002, 2003).
} 
component $)^{2}$ has ranged from $630000 \mathrm{t}$ in 2001 to $397000 \mathrm{t}$ in 2005 and was $569000 \mathrm{t}$ in 2009. Average price of mackerel was declining throughout the studied period (2001-2009), decreasing from 0.66 to 0.29 euro $\mathrm{kg}^{-1}$ (in constant euro with 2010 as base year). Bluefin tuna has been under recovery plan regulation from 2007 (Council Regulation 643/07), consequently TAC of this species declined from 32000 t 2006 to $22000 \mathrm{t}$ in 2009 . The price of bluefin tuna increased from 4.1 euro kg${ }^{-1}$ in 2001 to 5.3 euro $\mathrm{kg}^{-1}$ in 2009. Regarding albacore, in 2007 its TAC decreased from 34500 tonnes to 30200 with the aim of rebuilding the northern albacore stock from its overfished condition. According to ICCAT ${ }^{3}$, the albacore catch limit is $29000 \mathrm{t}$ and its price has remained stable around 3 to 4 euro $\mathrm{kg}^{-1}$.

\section{Materials and methods}

\subsection{Fisheries data}

The fleet data set used in this study includes technical and commercial information for each Basque purse-seiner vessel. This study deals with vessels that fished primarily in the Bay of Biscay and were based in Basque Country harbours. Landings analysed in this study were also made in Basque harbours. Landings taking place outside Basque Country have not been considered due to the non availability of data. In the case of anchovy, the market is mainly concentrated in the Basque country (ICES 2008) ${ }^{4}$ and so the Basque market is considered to be representative of the whole anchovy market. For the other species there is no data available on the percentage of the total landings made in the Basque Country by the Basque vessels.

The observed period was between 2001 and 2009, whereas the years prior to 2001 have not been analysed due to the lack of vessel identification in the database (the gears are not correctly allocated) and consequently the average landings by vessel for those years cannot be calculated. The specific variables used were: amount (kilograms and Euros) of landings by vessel, date and species; gross tonnage (GT) by vessel; price per kilogram of the landed species and number of operating vessels. Constant prices were calculated using the information on the Consumer Price Index published by INE, Spain (The National Statistics Institute ${ }^{5}$ ).

Variable and fixed costs were obtained from a sample representing $8 \%$ to $80 \%$ of the population depending on the year and fleet segment. Fixed costs were calculated as the sum of insurance, maintenance, depreciation and interest costs. Variable costs were calculated as the sum of landing and marketing,

\footnotetext{
${ }^{2}$ International Council for the Exploitation of the Sea (www.ices.dk). The stock is historically divided into three components, with the North Sea component is considered to have been over fished since the late 1970s, and the Western component contributes the vast majority of biomass and catch to the stock.

3 The International Commission for the Conservation of Atlantic Tunas (www.iccat.int).

4 ICES 2008, Long Term Management of Bay of Biscay Anchovy (SGBRE-08-01), San Sebastian, JRC 50506.

${ }^{5} \mathrm{http}: / /$ www.ine.es/jaxi/menu.do?type $=$ pcaxis $\&$ path $=\% 2 \mathrm{Ft} 25 /$ p138\&file $=$ inebase $\& \mathrm{~L}=0$
}

fuel, gear, crew and other variable costs. The average number of fishers by vessel was based on the annual sampling of the Basque purse seiner and bait boat fleet. Using 2008 as a reference year, the sample represented from $33 \%$ to $50 \%$ depending on the segment.

\subsection{Characterising fishing fleet}

The Basque purse-seiner fleet is a multispecies fleet that traditionally distributes its activity across three seasons: the mackerel season (from approximately February to May), the anchovy season (from approximately April to June) and the tuna season (from approximately June to November).

In the current analysis, two periods were considered. Period one concerned years 2001 and 2004: before the anchovy closure (years 2002 and 2003 were not taken into account due to the Prestige oil spill (González et al. 2006, 2009) which considerably affected fleet behaviour). The second period covered the anchovy closure from 2007 to 2009 (years 2005 and 2006 were not included because the anchovy fishery was opened for a short period).

Fleet landings by month were separated into two periods: before and after the anchovy closure. Then, overall landings by period and vessel were segmented by hierarchical cluster analysis of the Euclidean distance between landing profiles (proportion of mackerel, anchovy, albacore, bluefin tuna, coastal species and other species landings) using Ward's minimum variance criterion (Ward 1963). Then, a silhouette plot was used to select the number of clusters (Rousseeuw 1987). Intuitively, objects with a large silhouette width are well-clustered and those with a small silhouette width tend to lie between clusters. Kaufman and Rousseeuw (2008) suggest estimating the number of clusters by that which gives the largest average silhouette width.

\subsection{Defining the dependency on species}

In order to analyse the adaptability of the fleet, it is important to determine the alternatives that each fleet found during the anchovy closure. For do this, the economic dependency on each of the main species (anchovy, mackerel, bluefin tuna, albacore and coastal species) was calculated before and after the anchovy closure. Following from that, the economic dependence of segment $i$ on species $j$ is defined as:

$$
D_{i j}=V_{i j} / \sum_{j} V_{i j}
$$

where $V_{i j}$ is the revenue of the vessels in segment $i$ from selling species $j$ in a given year.

\subsection{Defining the fleet adaptability}

Adaptability is defined as the ability of the fleet to cope with fisheries closures. The following equation was used to define the adaptability:

$$
A D_{i}=\left[(V-C)_{i A C} / N B_{A C}\right] /\left[(V-C)_{i B C} / N B_{B C}\right]
$$


Cluster analysis before anchovy closure

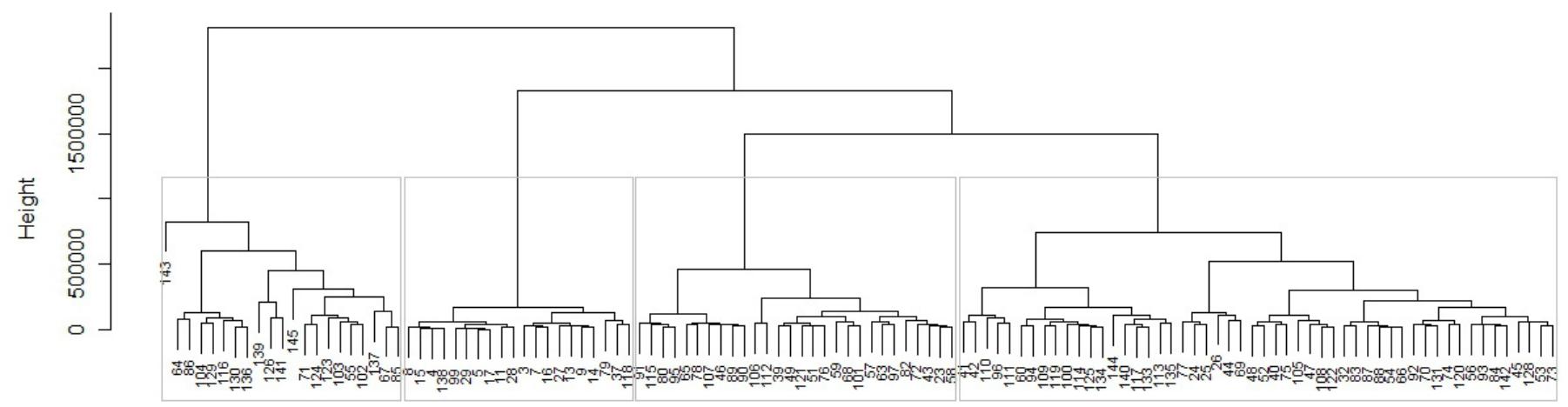

$\operatorname{dist}($ Aspecies)

hclust (*, "ward")

Fig. 1. Cluster analysis before anchovy closure. Results are presented as a dendrogram: the leaves are the initial element classes (the numbers labelling leaves are vessels) and the various "cuts" (by a horizontal line) of the dendrogram are various clustering of the data, into a decreasing number of classes. The grey line between clusters gives the largest average silhouette width in the cluster analysis before the anchovy closure.

where $(V-C)_{i A C}$ is the average turnover by vessel of segment $i$ after the anchovy closure and $(V-C)_{i B C}$ is the average turnover by vessel of segment $i$ before the anchovy closure and $N B$ is the number of vessels operating before or after the closure.

When the value of this indicator is equal to $100 \%$ it implies that segment $i$ adapted its behaviour perfectly during the closure, maintaining the same level of turnover as before. When the indicator is lower than $100 \%$, there is less than total adaptability of the segment. Adaptability depends on available substitute species and on the changes in fleet size that the fleet or the segment can experience. Finally, if it is above $100 \%$, this implies that the fleet has managed to increase its turnover. To compute the adaptability it was assumed that each fleet segment is always able to catch the same amount as the current fleet. This assumption was made considering that all the main species targeted by the current fleet are regulated by a TAC, meaning that catches are limited. If these fisheries had not been limited in this way, vessels could have landed higher amounts of fish. Consequently, it might be thought that, although the number of operating vessels is decreasing, they would be able to land more than they currently do. An example that confirms this idea is the mackerel fishery; in 2009, when the number of vessels was $59 \%$ of the operating fleet size in 2001, this small fleet was able to land much more mackerel (239\% more) than the larger fleet of 2001.

\section{Results}

\subsection{Fleet segmentation}

The fishing fleet of this study was selected on the basis of their primary fishing gear (purse seiner). Nevertheless, in the second semester of the year, a high percentage of this fleet changes its fishing gear in order to catch albacore and bluefin tuna. Around $73 \%$ of the vessels change their fishing gear from purse seiner to bait boat, and $11 \%$ to trolling gear. The remaining vessels do not change fishing gear during the year. Vessels were segmented into clusters (see method section, Fig. 1).

According to the cluster analysis carried out before the anchovy fishery closure, the fleet was separated into four segments. The segmentation depended on the landing profiles. In this study four fleet segments were analysed separately. Segment 1 (S1) was the segment composed of the largest vessels of the fleet and whose dependence on the anchovy was the highest. Segment 2 (S2) was the segment with the lowest average GT by vessel and whose dependence on the anchovy was the lowest. Segment 3 (S3) and segment 4 (S4) were composed of vessels with similar GT. The difference between these two segments is that while S3 depended highly on bluefin tuna, S4 did to a lesser extent due to the fact that it focused its catches on albacore more than on bluefin tuna.

\subsection{Changes in the Basque purse-seiner fleet in the Bay of Biscay}

In general terms, the evolution of average GT by vessel of the fleet had a positive slope in all segments before and after the anchovy fishery closure. In parallel, the number of vessels of the Basque purse-seiner fleet decreased throughout the period of time considered. From these two trends, it can be deduced that after the anchovy fishery closure there were fewer vessels with higher average GT by vessel operating in the fishery than before.

Technical characteristics of each segment have been evaluated. The average GT by vessel increased 12\%, 70\%, 18\% and $34 \%$ for segments S1, S2, S3 and S4 respectively from 2001 to 2009 (Fig. 2). From the previous year to the fishery closure (2004) to the 2009, the number of vessels in general was reduced by $32 \%$. The overall landing value of the fleet decreased throughout the anchovy ban, so the non-availability of 


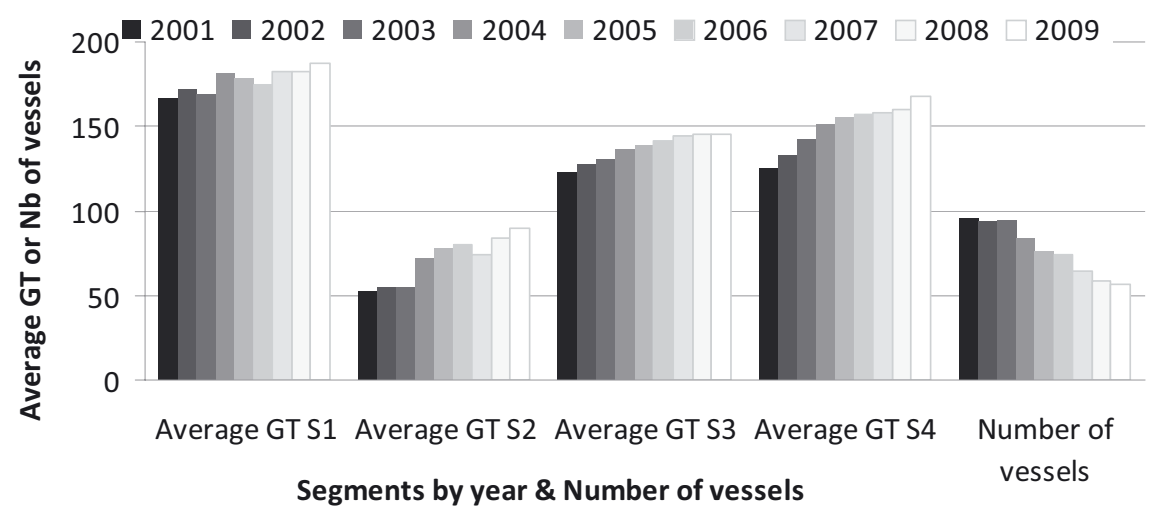

Fig. 2. Average GT by segment from 2001 to 2009; number of vessels operating in the Basque purse-seiner fleet per year (far right).
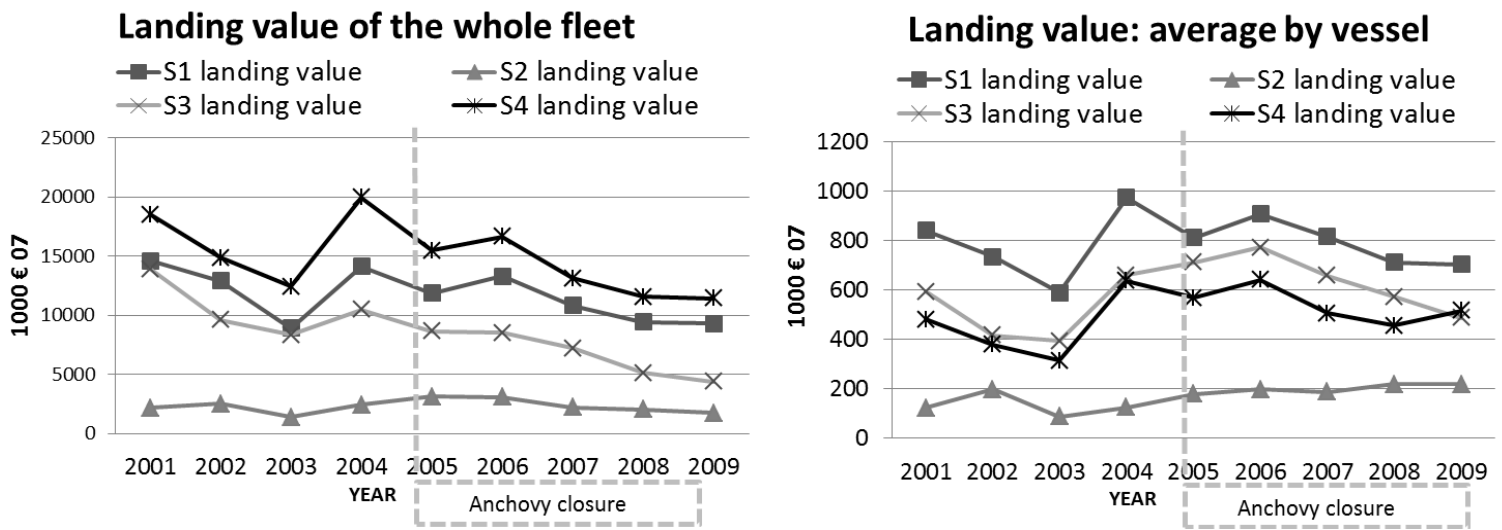

Fig. 3. Right: overall landing value of the Basque purse-seiner fleet by segment (S1, S2, S3, S4), measured in constant euros with 2007 as a base year. Left: average landing value by vessel, year and segment.

anchovy could be one of the main factors that have prompted this decrease in overall income (Fig. 3). During this same period, the number of vessels of the Basque purse-seiner fleet fell ${ }^{6}$. Consequently, the economic impact by vessel might have been offset by the lower number of ships operating in the fishery. As Figure 3 shows, the decrease in average landing values by vessel was not as steep as for the whole fleet, especially in case of S2.

\subsection{General changes in the fishing patterns}

The Basque purse-seiner fleet is a sequential fishery; however, some fisheries overlap for certain periods of the year. In

\footnotetext{
${ }^{6}$ The Basque purse seiner fleet reduced its size by $40 \%$ from 2001 to 2009. The fleet reduction was driven by some council regulations, including the Council Regulation (EC) No. 2798/1999 of 17 December outlining the public aid available for renewal of fishing vessels which may be granted until 31 December 2004. In 2002, the public aid for fleet renewal became more restrictive. With regard to scrapping, the Council Regulation (EC) No. 2370/2002 of 20 December 2002 established an emergency Community measure for scrapping fishing vessels, which consists of a special incentive to provide Member States with funds to co finance their additional needs to scrap fishing vessels. The Basque Country fleet began to receive money from the ship scrapping fund in 2003.
}

particular, the anchovy fishery season overlaps with the mackerel and bluefin tuna seasons (at the beginning and at the end of anchovy fishery season, respectively). Consequently, the anchovy fishery closure could have influenced the fisher's behaviour and thus affected the overlapped fisheries.

Anchovy from the Bay of Biscay was a species highly valued by consumers and by the canning industry. In contrast, mackerel had a very low price especially in year 2009 with an average price of 0.3 euro $\mathrm{kg}^{-1}$. The mackerel fishery was not significant in the month of February $(0.3 \%$ of the total landed mackerel) until 2005, when the fishery was closed. From that year the Basque purse-seiner fleet reallocated its effort, bringing forward the mackerel season from March to February (except 2006, when the anchovy fishery was reopened for a short time). Hence, the mackerel effort reallocation strengthened during the anchovy fishery closure, as shown in Figure 4. However, the average constant price (with 2010 as a base year) of this species decreased by $56 \%$ from 2001 to 2009; consequently, in economic terms, mackerel was not able to compensate for the loss of revenues during the anchovy fishery closure (Fig. 5). There was an exception in 2009, however, when the value of mackerel landings was similar to anchovy landing value in 2003, which could indicate that mackerel could have compensated for the anchovy loss.

During the anchovy closure there was also an early initiation of the bluefin tuna fishing season (Fig. 6). Most of the 


\section{Mackerel (Scomber scombrus)}

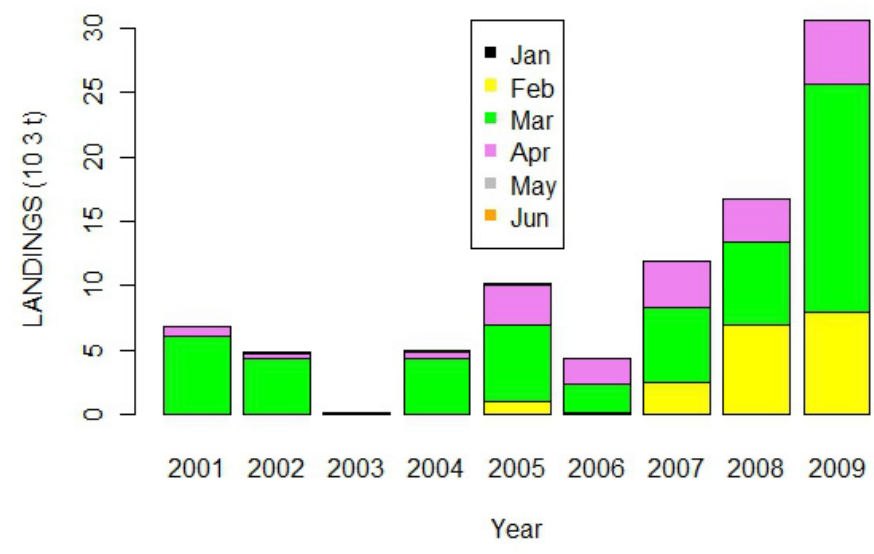

Fig. 4. Monthly mackerel (Scomber scombrus) landings (kg) by the Basque purse seiners from 2001 to 2009: during the closure of the anchovy fishery, the mackerel season started in February instead of March.

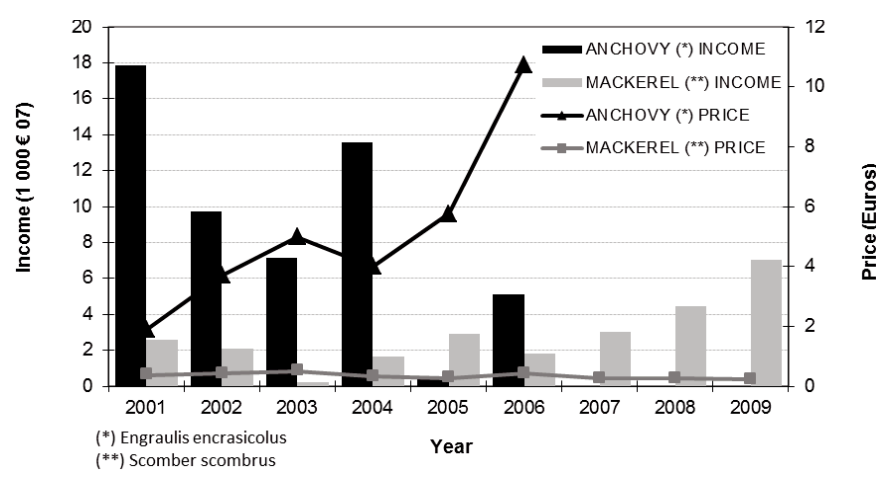

Fig. 5. Yearly income and price of anchovy (Engraulis encrasicolus) and mackerel (Scomber scombrus) in constant euros (with 2007 as a base year) for the entire fleet. The anchovy price reached its maximum value in 2006. Mackerel has a lower price compared with anchovy.

purse seiners used to shift from anchovy to bluefin tuna (which is usually available to the fishery slightly earlier than the albacore) by mid June or the beginning of July. Since the anchovy fishery closure, most of fleet made some trips targeting bluefin starting from mid-June and lasting until the appearance of albacore in the area or the fulfilment of the fishing quota. Although it can be thought that there had been early accessibility of bluefin tuna, the fact is that before the anchovy closure, most of the vessels had not changed their fishing gear from purse seiner to bait boat until the anchovy fishery was finished. Another factor that altered the revenues of the Basque purse-seiner fleet was the reduction in the bluefin quota share allocation. The implementation of the recovery plan for bluefin tuna (Council Regulation 643/07) ${ }^{7}$ has limited the catches of this species (Artetxe et al. 2008).

\footnotetext{
${ }^{7}$ Council Regulation (EC) No. 643/2007 of 11 June 2007 amending Regulation (EC) No. 41/2007 as concerns the recovery plan for bluefin tuna recommended by the International Commission for the Conservation of Atlantic Tunas.
}

From 2005 onwards, landings of all the species in May were nearly zero. One of the possible reasons for this temporary halt in fishing activities was the financial compensation for not fishing for a maximum period of 40 days.

Coastal species landings increased noticeably during the anchovy ban. Although the coastal species represented only the $3 \%$ of the total revenues for the whole fleet before the anchovy ban, some vessels have found an alternative source of revenues in these species during the anchovy closure (Fig. 7).

\subsection{Economic dependence and contribution of fishing segments}

At this point we only considered those vessels that were operating before and after the anchovy fishery closure. In economic terms, before the anchovy fishery closure, this was one of the most important species for all fleet segments (Table 1) even though the segments differed. In case of S1, the most important species was the anchovy, followed by albacore and the group of "others" 8 . In the case of S2, the sum of coastal and others species reached $45 \%$, and anchovy $25 \%$. In contrast, S3 did not catch any coastal species before the closure, and its principal species were anchovy and bluefin tuna. S4 obtained $84 \%$ of total landing value through anchovy, albacore and mackerel. However, when the anchovy fishery was closed, the situation changed completely. Focusing on the overall income by vessel, S1, S3 and S4 had a lower landing value during the anchovy closure (18\%, 9\% and $17 \%$ respectively). S2 had not only maintained but also increased its average landing value compared with before the anchovy fishery closure (Fig. 7). The segment with the lowest economic dependence on anchovy was $S 2$, which was the only one that managed to improve its economic status during the anchovy fishery closure. S1 increased its landing value from bluefin tuna and mackerel during the closure. In contrast, the landing value of coastal and other species was lower during the anchovy ban. S2 increased its landings in all species, in particular bluefin tuna and mackerel landings value increased sharply in relative terms. S3 increased its landings values of mackerel and albacore. All vessels of this segment changed their fishing gear from purse seiner to bait boat. Traditionally its landings of coastal species were null but, with the anchovy fishery closure, S3 started fishing coastal species. S4 landed a higher amount of mackerel and bluefin tuna during the closure. From these findings, it can be deduced that the anchovy shortage had been partly compensated by fishing large pelagic fish and mackerel.

\subsection{Financial compensation}

Fishers and ship-owners had received compensation for temporary cessation during the anchovy fishery closure. The state compensation ${ }^{9}$ is a daily aid of 45 euro day $^{-1}$ per crew member for a maximum of 40 days without any fishing activity. Obviously, this financial compensation modified the

\footnotetext{
8 "Others" refers to all species excluding anchovy, mackerel, bluefin tuna, albacore and coastal species.

9 Order PRE/2718/2005, 19 August; 2005, Order PRE/3913/2006, 22 December 2006; Order PRE/2475/2007, 10 August; Order PRE/3518/2008, 3 December; Order PRE/3383/2009, 15 December.
} 


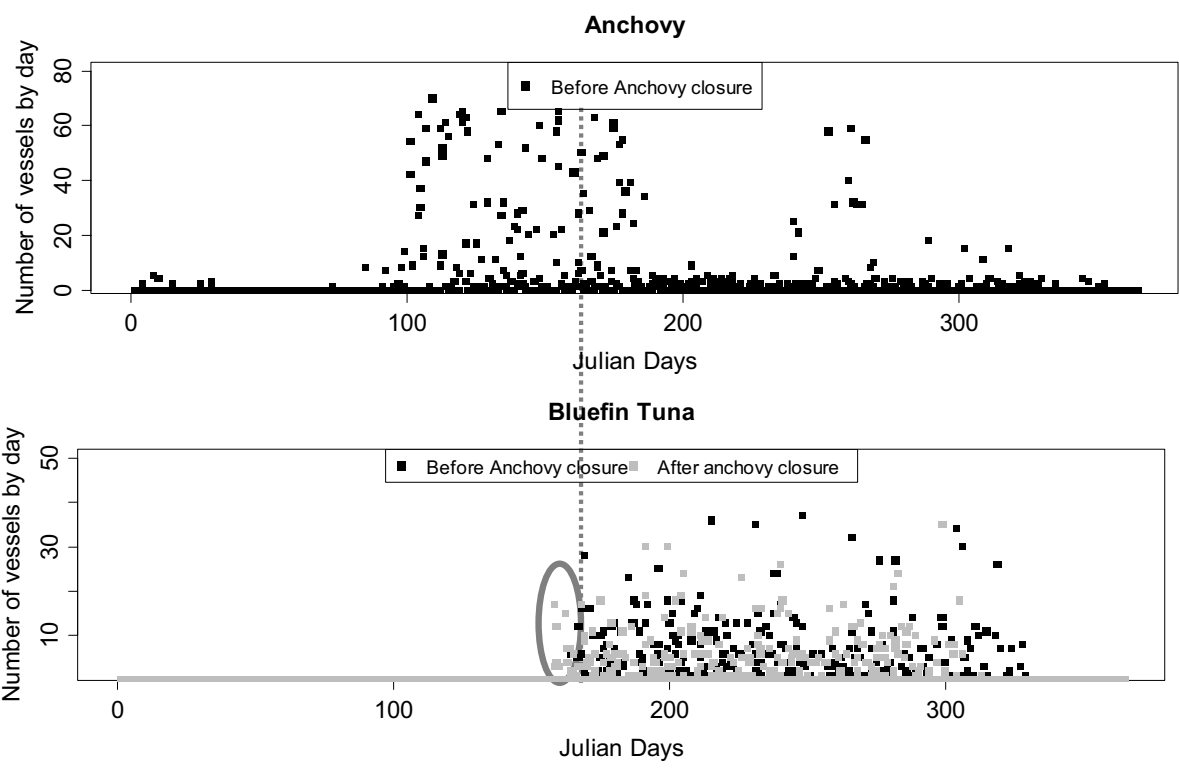

Fig. 6. Number of vessels that landed anchovy before and after anchovy closure (in Julian days). Grey dots correspond to the period after the anchovy closure; black points to the period before anchovy closure. The circle indicates those vessels that started the bluefin tuna (not albacore) fishery early.
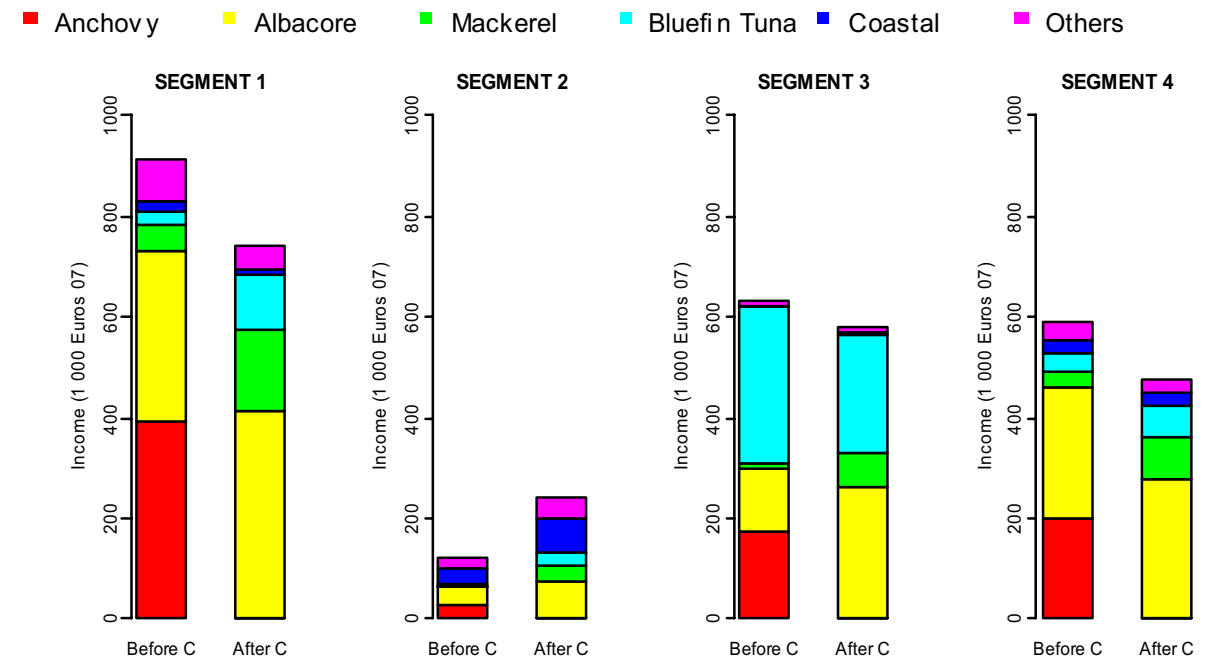

Fig. 7. Average landing value by vessel in constant euros (with 2007 as a base year) species and segment operated both before and after the anchovy closure: before the closure (before C, 2001, 2002 and 2004); after the closure (after C, 2006, 2007, 2008 and 2009). Vessels represented are those that operated before and after the anchovy closure.

fisher's behaviour, which then reduced the fishing activity in May, coinciding with the anchovy season. The question here is of whether the aid granted to fishers was of such a level that fishers managed to maintain their income despite the anchovy ban. The answer is not exactly the same for all segments. By studying the adaptability it was possible to analyse to what extent the financial compensation affected each segment.

\subsection{Adaptability}

Adaptability, as defined in Section 3.4, was measured for all segments. For S1, S3 and S4 the adaptability in the anchovy ban was $81 \%, 91 \%$ and $83 \%$, respectively (Fig. 8), which implies that they had not been able to maintain their revenues throughout the anchovy fishery ban period. In contrast, S2 obtained $192 \%$. This implies that the landing value of this segment increased during the anchovy fishery ban compared with the period immediately before it.

As can be seen in equation (4), adaptability is directly related to the landings profile and fleet size adjustment. We analysed only those vessels that operated before and during the closure, if we analysed all vessels (from Fig. 1), the fleet size reduction from 2004 to 2009 of S1, S2, S3 and S4 would had been $6 \%, 63 \%, 43 \%$ and $33 \%$ respectively. S2 had a larger decrease in fleet size than the other segments. The adaptability of 
Table 1. Economic dependence on the main species landed by the different segments before (2001, 2002 and 2004) and during (2007, 2008 and 2009) the anchovy closure; average landing value by vessel ( $10^{3}$ constant euros with 2007 as a base year); and average landing amount (kg) by vessel and landing profile of the whole Basque purse-seiner fleet.

\begin{tabular}{|c|c|c|c|c|c|c|c|c|}
\hline & Closure & Units & Anchovy & Albacore & Mackerel (*) & Bluefin tuna & Coastal species $(* *)$ & Others \\
\hline \multirow{6}{*}{ Segment 1} & \multirow{3}{*}{ Before } & $\%$ & $43 \%$ & $37 \%$ & $6 \%$ & $3 \%$ & $2 \%$ & $9 \%$ \\
\hline & & $\mathrm{kg}$ & 163004 & 112803 & 153182 & 10230 & 8874 & 189557 \\
\hline & & $1000 €$ & 438 & 375 & 59 & 32 & 20 & 93 \\
\hline & \multirow{3}{*}{ After } & $\%$ & $0 \%$ & $55 \%$ & $22 \%$ & $15 \%$ & $1 \%$ & $7 \%$ \\
\hline & & $\mathrm{kg}$ & 0 & 119812 & 556340 & 23059 & 2277 & 147187 \\
\hline & & $1000 €$ & 0 & 458794 & 182247 & 124640 & 8239 & 55107 \\
\hline \multirow{6}{*}{ Segment 2} & \multirow{3}{*}{ Before } & $\%$ & $25 \%$ & $26 \%$ & $1 \%$ & $3 \%$ & $26 \%$ & $19 \%$ \\
\hline & & $\mathrm{kg}$ & 9178 & 8744 & 2675 & 542 & 11363 & 23071 \\
\hline & & $1000 €$ & 34154 & 36302 & 1906 & 4006 & 35806 & 27171 \\
\hline & \multirow{3}{*}{ After } & $\%$ & $0 \%$ & $31 \%$ & $13 \%$ & $12 \%$ & $27 \%$ & $17 \%$ \\
\hline & & $\mathrm{kg}$ & 0 & 23402 & 118378 & 6721 & 21363 & 46816 \\
\hline & & $1000 €$ & 0 & 83503 & 33734 & 32633 & 73314 & 45658 \\
\hline \multirow{6}{*}{ Segment 3} & \multirow{3}{*}{ Before } & $\%$ & $28 \%$ & $19 \%$ & $2 \%$ & $49 \%$ & $0 \%$ & $1 \%$ \\
\hline & & $\mathrm{kg}$ & 58955 & 33440 & 38212 & 71748 & 0 & 14295 \\
\hline & & $1000 €$ & 197178 & 134024 & 15930 & 348686 & 0 & 9716 \\
\hline & \multirow{3}{*}{ After } & $\%$ & $0 \%$ & $45 \%$ & $12 \%$ & $41 \%$ & $0 \%$ & $2 \%$ \\
\hline & & $\mathrm{kg}$ & 0 & 76992 & 258337 & 52058 & 1535 & 24724 \\
\hline & & $1000 €$ & 0 & 292618 & 75020 & 264629 & 1281 & 11757 \\
\hline \multirow{6}{*}{ Segment 4} & \multirow{3}{*}{ Before } & $\%$ & $34 \%$ & $44 \%$ & $5 \%$ & $7 \%$ & $5 \%$ & $6 \%$ \\
\hline & & $\mathrm{kg}$ & 57611 & 76305 & 72437 & 10153 & 10768 & 52829 \\
\hline & & $1000 €$ & 225584 & 290458 & 31314 & 43378 & 30096 & 38287 \\
\hline & \multirow{3}{*}{ After } & $\%$ & $0 \%$ & $58 \%$ & $18 \%$ & $13 \%$ & $5 \%$ & $6 \%$ \\
\hline & & $\mathrm{kg}$ & 0 & 85444 & 325390 & 14811 & 9111 & 46150 \\
\hline & & $1000 €$ & 0 & 284353 & 86081 & 65893 & 24874 & 27653 \\
\hline
\end{tabular}

(*) Mackerel is referred only to Scomber scombrus.

(**) Mediterranean horse mackerel, saddled bream, bogue, sargos, striped sea bream, gilthead sea bream, axilary sea-bream, bass, pandora, Atlantic bonito and chub mackerel.

S2 was much larger. Therefore, it can be deduced that the fleet reduction in the case of $\mathrm{S} 2$ was enough to achieve at least the same level of average revenues by vessel as before the anchovy fishery closure.

Finally, the fleet size reduction necessary to maintain the same level of profit as before the anchovy closure was computed. To do this, adaptability was calculated for several fleet reduction levels (from 5\% to 80\%), considering the year prior to the anchovy closure as the reference year. In this section, costs were subtracted from the landing value to calculate the average profit by vessel. To obtain a $100 \%$ score of adaptability, S1 would have to reduce its fleet by around $28 \%, \mathrm{~S} 3$ by around $23 \%$ and S4 by around $24 \%$, while S2 would not have to reduce anything (Fig. 8). These percentages were calculated without considering financial compensation. Furthermore, the financial compensation for not fishing did not significantly change the adaptability of any of the segments analysed (27\%, 20\% and $21 \%$ for segments S1, S3 and S4 respectively). S2 did not need financial compensation to achieve the $100 \%$ adaptability.

\section{Conclusion}

The profitability of the Spanish purse-seiner fleet before the implantation of the moratorium was statistically higher than after the moratorium (Garza-Gil et al. 2011), but the impact of the anchovy fishery closure change was not necessarily equal for all vessels that belong to this fleet, due to the fact that the Spanish fleet as a whole is not homogenous. In the case of the Bay of Biscay, fleet adjustment and fishing profile are the main factors that determine the impact of the closure. As the fishing profile was different between segments, the impact on each segment was also different, as in the case of Basque purse-seiner fleet.

S1 was negatively affected by the anchovy fishery closure. Although S1 had achieved the highest level of income comparing to the rest of the segments, its decrease of profit $(25 \%$ if the financial compensation is included) during the anchovy fishery closure was the highest of all the segments. S1 had the highest dependence on anchovy and its number of vessels decreased less than the other segments. During the anchovy ban, S1 increased its landings of mackerel but the mackerel income did not increase to such an extent due to the fact that the price of this species decreased significantly. Furthermore, S1 increased its landings of bluefin tuna, but it appears that this was not enough to maintain the same level of profits as before the closure.

In the case of $\mathrm{S} 2$, the anchovy ban did not have a clear negative impact on the average income by vessel; the average landing value by vessel increased by $93 \%$ during the closure and its profit increased $125 \%$ (166\% with financial compensation). 


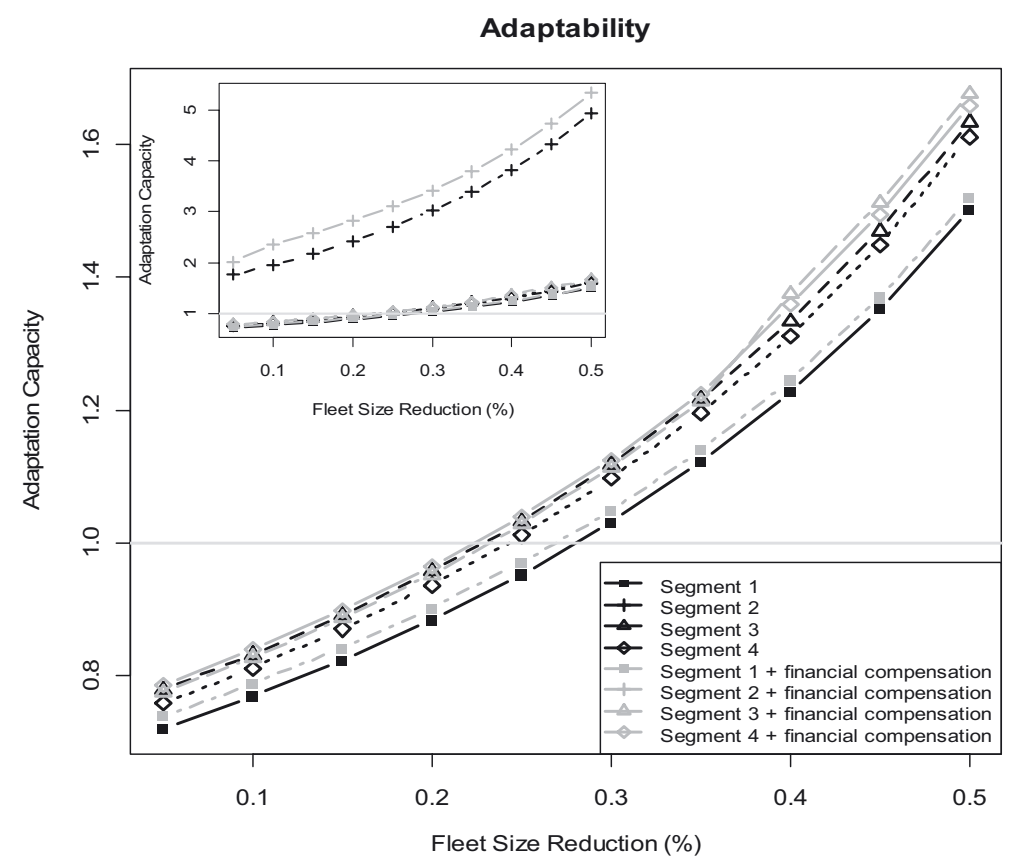

Fig. 8. Right: adaptability in several fleet reduction scenarios. The $X$-axis represents the percentage of fleet reduction and the $Y$-axis represents adaptability axis for each level of fleet reduction. The financial compensation was estimated as the average number of fishermen working on a vessel multiplied by 40 days and by 45 euro day ${ }^{-1}$. Insert: adaptation capacity in all segments.

This could be explained by two main reasons. Firstly, S2 was the segment with lowest economic dependence on anchovy. Secondly, S2 proportionally increased its landings of all the other species, especially bluefin tuna and mackerel. In any case, S2 was the segment with a lowest level of income. Although in absolute terms, the increase of landings were not as high as in other segments, in relative terms the landings increase was much greater for S2 than for S1, S3 or S4. Additionally, S2 was one of the segments with a highest reduction of the fleet size, which could have positively influenced average income by vessel.

$\mathrm{S} 3$ experienced the most drastic fleet size reduction (62\%) during the studied period (2001-2009). Additionally, S3 started fishing coastal species and increased the level of mackerel and bluefin tuna landings during the anchovy ban. Nevertheless, closure significantly affected the S3, reducing its landing value by $9 \%$ and the profit by $14 \%$ (10\% including financial aids).

The anchovy fishery closure also negatively affected S4, despite its $43 \%$ fleet size decrease. Although S4 increased its landings of mackerel and, to a lesser extent, landings of albacore and bluefin tuna, this segment had not been able to maintain the same level of income as before the closure. S4 have decreased its profit by $22 \%$ (18\% if the financial compensation is included).

All segments have reallocated their effort towards the mackerel fishery, but the price of this species has decreased significantly and the loss prompted by the anchovy ban was not compensated by the mackerel landings. All segments increased the income from bluefin tuna and/or albacore.

Even though all segments had a high economic dependence on the anchovy fishery before the anchovy fishery ban, the effects of the closure on the S2 were not as negative as for the other segments. This can be explained through adaptability, which depends on the fleet size adjustment and fishing profile. From the results it can be deduced that the effort reallocation together with fleet size reduction carried out by S2 was more effective than the strategies of the other segments for maintaining income. In any case, and considering fishing costs, all segments maintained a positive profit thorough the closure.

This study provides some insights into the impact of a fishery closure on the fleet. Firstly, the fleet cannot be studied as a whole given that there are significant differences between the vessels that make up the fleet. Secondly, although the economic dependence on the fishery can be more or less the same for all the segments, the fishing alternatives can vary according to the technical characteristics of the fleet and the availability of alternative species.

The same management measure can affect each segment of the same fleet in different ways. Therefore, it could be useful to take into account the adaptability in fisheries management. Moreover, when the target fleet is a multispecies fleet, limitations on alternative species would have to be studied since they have a great influence on adaptability.

Another point to take into account is the financial compensation given to the fishers by the government throughout the anchovy ban. As the closure does not affect all vessels equally, the financial aid should be higher for those vessels with a lower adaptability. The granted aid in the anchovy fishery closure did not have a compensatory effect between segments. On the contrary, the aid has had a better effect in case of S2 than for the other segments, because the aid depended on the number of crew members and not on the adaptability of the segment.

In terms of number of vessels, the larger the fleet size adjustment is, the higher the adaptability. At this point, it is necessary to analyse how this adjustment affects the social 
reality of fishers. Each boat is a source of employment for fishers; consequently, a sharp reduction of fleet size could pose a high risk to this collective. Therefore, further studies could develop a social indicator of adaptability of the fishers in the labour market when they leave the fishing activity.

Acknowledgements. We acknowledge the helpful comments and data provided by Xabier Irigoien, Richard Curtin, Luis Arregi, Andrés Uriarte, Josu Santiago, Lucia Zarauz and Iñaki Artetxe. We are also grateful to two anonymous reviewers for their extensive suggestions and thoughtful comments.

This study, which was carried out within the EcoANCHOA project, was funded by the Basque and Spanish Ministries for Fisheries and Agriculture and the European Fisheries Fund. This paper is contribution $\mathrm{N}^{\circ} 582$ from AZTI-Tecnalia (Marine Research).

\section{References}

Andonegi E., Fernandes J.A., Quincoces I., Irigoien X., Uriarte A., Pérez A., Howell D., Stefánsson G., 2011, The potential use of a gadget model to predict stock responses to climate change in combination with Bayesian networks: the case of Bay of Biscay anchovy. ICES J. Mar. Sci. 68, 1257-1269.

Aranda M., Murillas A., Motos L., 2006, La base del conocimiento en la gestión de pesquerías: el caso del sistema de mandato y control de la Unión Europea. Rev. Galega Econ. 15, No. 1.

Arregi L., 2009, Análisis de los desembarcos de la flota de cerco costera en los puertos del País Vasco. Final report, Dir. Innovación y Desarrollo Tecnológico, Viceconsejería de Política e Industria Alimentaria, Dpto. Agricultura, Pesca y Alimentación, Eusko Jaurlaritza, Gobierno Vasco.

Artetxe I., González de Zarate A., Ruiz J., 2008, Implantación en el País Vasco del plan de recuperación del atún rojo (Reglamento CE 643/07). Rev. Invest. Mar. 5, 15 p.

Branch T.A., Hilborn R., Haynie A.C., Fay G., Flynn L., Griffiths J., Marshall K.N., Randall J.K., Scheuerell J.M., Ward E.J., Young M., 2006, Fleet dynamics and fishermen behavior: lessons for fisheries managers. Can. J. Fish. Aquat. Sci. 63, 1647-1668.

Charles A.T., 2001, Sustainable fishery systems. Fish and aquatic resources series. Oxford: Blackwell Science.

Daures F., Rochet M.J., Van Iseghem S., Trenkel V.M., 2009, Fishing method, economic dependence and fish community impacts of French fleets in the Bay of Biscay during 2000- 2006. Aquat. Living Resour. 22, 535-547.

Fulton E.A., Smith A.D.M., Smith D.C., van Putten I.E., 2011, Human behaviour: the key source of uncertainty in fisheries management. Fish Fish. 12, 2-17.

Garcia S.M., Charles A.T., 2008, Fishery systems and linkages: implications for science and governance. Ocean Coast. Manage. 51, 505-527.

Garza-Gil M.D., Varela-Lafuente M.M., Caballero-Miguez G., Álvarez Díaz G., 2011, Analysing the profitability of the Spanish fleet after the anchovy moratorium using bootstrap techniques. Ecol. Econ. 70, 1154-1161.

González M., Uriarte A., del Campo A., Egia N., Valencia V., Alzola E., Pozo R., 2009, Una revisión de la crisis creada por el accidente del Prestige en la costa del País Vasco: lecciones para el futuro. Rev. Invest. Mar. 12.

González M., Uriarte A., Pozo R., Collins M., 2006, The Prestige crisis: operational oceanography applied to oil recovery, by the Basque fishing flet. Mar. Pollut. Bull. 53, 369-374.
Hilborn R., 2006, Fisheries success and failure: the case of the Bristol Bay salmon fishery. Bull. Mar. Sci. 78, 487-498.

Hilborn R., 2007, Managing fisheries is managing people: what has been learned? Fish Fish. 8, 285-296.

Ibaibarriaga L., Fernández C., Uriarte A., 2011, Gaining information from commercial catch for a Bayesian two-stage biomass dynamic model: application to Bay of Biscay anchovy. ICES J. Mar. Sci. 68, 1435-1446.

Kaufman L., Rousseeuw P.J., 2008, Introduction, in finding groups in data: an introduction to cluster analysis, John Wiley \& Sons, Hoboken.

Lehuta S., Mahévas S., Petitgas P., Pelletier D., 2010, Combining sensitivity and uncertainty analysis to evaluate the impact of management measures with ISIS-Fish: marine protected areas for the Bay of Biscay anchovy (Engraulis encrasicolus) fishery. ICES J. Mar. Sci. 67, 1063-1075.

Mahevas S., Vermard Y., Hutton T., Iriondo A., Jadaud A., Maravelias D.C., Punzón A., Sacchi J., Tidd A., Tsitsika E., Marchal P., Goascoz N., Mortreux S., Roos D., 2011, An investigation of human vs. technology-induced variation in catchability for a selection of European fishing fleets. ICES J. Mar. Sci. 68, 2252-2263.

Poos J.J., Rijnsdorp A.D., 2007, An "experiment" on effort allocation of fishing vessels: the role of interference competition an area specialization. Can. J. Fish. Aquat. Sci. 64, 304-313.

Powers J.E., Abeare S.M., 2009, Fishing effort redistribution in response to area closures. Fish. Res. 99, 216-255.

Rijnsdorp A.D., Piet G.J., Poos J.J., 2001, Effort allocation of the Dutch beam trawl fleet in response to a temporarily closed area in the North Sea. Internat. Counc. Explor. Sea, Copenhagen, ICES CM 2001/N:01.

Rodriguez-Marin E., Moreno G., Rodriguez-Cabello C., Ortiz M., Arrizabalaga H., 2002, Description and evolution of the baitboat fleet targeting bluefin tuna in the Bay of Biscay from 1975 to 2000. SCRS/2001/131. Col. Vol. Sci. Pap. ICCAT 54, 561-573.

Rodriguez-Marin E., Arrizabalaga H., Ortiz M., Rodriguez-Cabello C., Moreno G., Kell L.T., 2003, Standardization of bluefin tuna, Thunnus thynnus, catch per unit effort in the baitboat fishery of the Bay of Biscay (Eastern Atlantic). ICES J. Mar. Sci. 60, 1216-1231.

Rousseeuw P.J., 1987, Silhouettes: a graphical aid to the interpretation and validation of cluster analysis. J. Comput. Appl. Math. 20, 53-65.

Ruitenbeek H.J., 1996, The great Canadian fishery collapse: some policy lessons. Ecol. Econ. 19, 103-106.

Salas S., Gaertner D., 2004, The behavioural dynamics of fishers: management implications. Fish Fish. 5, 153-167.

Sethi S.A., 2010, Risk management for fisheries. Fish Fish. 11, 341-365.

Torres-Irineo E., Gaertner D., Delgado de Molina A., Ariz J., 2011, Effects of time-area closure on tropical tuna purse-seiner fleet dynamics through some fishery indicators. Aquat. Living Resour. 24, 337-350.

Vermard Y., Marchal P., Mahévas S., Thébaud O., 2008, A dynamic model of the Bay of Biscay pelagic fleet simulating fishing trip choice: the response to the closure of the European anchovy (Engraulis encrasicolus) fishery in 2005. Can. J. Fish. Aquat. Sci. 65, 2444-2453.

Villamor B., Aranda M., Punzón A., Uriarte A., Báez J.C., 2008, The anchovy fishery in the Bay of Biscay: description and analysis of the Spanish fleet (2000-2005). ICES CM 2008/:30.

Ward J.H., 1963, Hierarchical grouping to optimize an objective function. J. Am. Stat. Assoc. 58, 301, 236-244. 